\title{
Editorial
}

\section{The cardiovascular epidemic with particular emphasis on the Muslim world}

\author{
ARA Rashid*
}

\section{Introduction}

Cardiovascular Disease (CVD) is a global epidemic. It is the leading cause of death worldwide and more importantly contributes to most of the premature death especially in the developing world. Over the next two decades the prevalence of CVD has been projected to double in the developing world. The main reason for this explosion is the projected increase in the prevalence of cardiovascular risk factors which leads to cardiovascular diseases. In the most world's populous nation, China, elevated blood pressure has been identified has the leading cause of premature death $^{1}$. This increase in prevalence of cardiovascular risk factor profile in the developing world is in a major way contributed by the adoption of a more westernise life style and habits. This includes sedentary lifestyle, increase consumption of western style fast food with high saturated fat content and smoking. These plus the relative lack of resources allocated for health spending in many developing world will inevitably lead to further health burden to the society.

The Muslim world consists of over 1.6 billion people. Although the Muslim land is mainly confined to countries between the Atlantic ocean in the west and the South China sea in the east, Muslim communities are now present in almost all corners o the world from the northern most tip of Canada to South Africa, Argentina and Australasia. With very few exceptions, most countries in the Muslim worlds are classified socioeconomically as underdeveloped or developing, collectively defined by the World Health Organisation as Low and Middle Income Countries (LMIC) The cardiovascular burden is ubiquitous among the Muslim population. Even in the newly developed Muslim world (High Income Countries), cardiovascular risk factors and cardiovascular diseases are on the rise. This is in contrast with non Muslim developed world where cardiovascular disease is no longer the main cause of death being overtaken by cancer ${ }^{2}$. This short article will explore the extend of the cardiovascular epidemic among the Muslim world, the possible explanations and propose some measure which may InshaAllah (God Willing) stem the tide of cardiovascular diseases in the ummah (society).

\section{Health and the Muslim world}

In terms of life expectancy, no country in the Muslim world made it to the top 30 according to data from the United Nation for the period from 2005-2010. The United Arab Emirates has a life expectancy of 78.7 years, the highest in the Muslim world but ranked $31^{\text {st }}$ in the world. According to the United Nations ${ }^{3}$, only three other Muslim nations made it to the top 50, Kuwait (77.6 years ranked 41), Brunei (77.1 years ranked 43) and Albania (76.4 years ranked 45). Life expectancy estimate for 2011,according to the American Central Intelligence Agency also did not list any Muslim nations in the top 30 and listed only 1 Muslim nation in the top 50 (Bosnia Herzegovina ;78.8 years at number 45) followed by with Kuwait with a life expectancy of 78.15 years at a lowly $52^{\text {nd }}$ position. There have however been important improvements with some success stories from the Muslim world ${ }^{5}$ but more needs to be done to improve the health profile of Muslim nations. Realising this, the Organisation of Islamic Conference had in 2005 released a document which will act as a blue print of action for the $21^{\text {st }}$ Century to tackle the various problems of the ummah including that on health issues ${ }^{6}$.

*Corresponds to: Abdul Rashid Abdul Rahman, Center For Graduate Studies, Research and Commercialisation, Cyberjaya University College of Medical Sciences, Cyberjaya, Malaysia. Email: rashid@cybermed.edu.my. 


\section{Cardiovascular disease in the Muslim world}

Latest available statistics from the World Health Organisation (WHO) showed that death from cardiovascular diseases is the number one cause of mortality. It constitutes $30.5 \%$ of all death worldwide. Countries in the Eastern Mediterranean, South and South Asia and the Western Pacific are the biggest contributor to $\mathrm{CV}$ death ${ }^{7}$. These are also regions where the majority of the Muslim population in the world reside. South and South East in particular have close to three quarters of a billion Muslims, more than any other region in the world. The region is the second biggest contributor of $\mathrm{CV}$ death second only to the Western Pacific Region where China contributes the most. South Asia itself contributes to the highest CVD burden compared to other region globally $^{8}$. In the EUROASPIRE survey, data from Turkey showed important differences between herself and other European countries. There were younger patients with myocardial infarction; the smoking rate was higher with a lower HDL C levels ${ }^{9}$. Indonesia, the most populous Muslim country is undergoing and epidemiological transition with cardiovascular disease challenging infectious disease in disease burden ${ }^{10}$. In the meanwhile, stroke in the Arab world though not as prevalent as in Western World is similar to that of China ${ }^{11}$.

\section{Cardiovascular risk factors in the Muslim world}

There has been a dearth of published good quality prospective data from the Muslim world as regards cardiovascular risk profiling. Malaysia arguably leads the Muslim world in this respect because since the early 1980s cardiovascular disease had been recognised as the leading cause of mortality in the country and was projected to remain so well into 2020 . One of the steps taken by the Ministry of Health was to commission periodic survey of the status of cardiovascular risk factors among the Malaysian population. So far 3 nationwide surveys has been conducted over 3 decades called collectively the National Health and Morbidity Surveys 1,2 and 3 done in 1986,1996 and 2006 respectively. These surveys involving at least 20,000 respondents in each survey showed a worrying trend. All major cardiovascular risk factors showed an increase in prevalence except for smoking where the prevalence has dropped slightly from 1996 to 2006 (from 25\% to 22\%) but with a worrying trend of more adolescent smokers especially among females ${ }^{12}$. The biggest relative rise in prevalence from 1996 to 2006 was seen with diabetes $(80 \%)$ followed by obesity (63\%) and hypertension (29\%). Similar studies looking at national temporal trends in CV risk factor profile from other Muslin world is unfortunately lacking.

Cardiovascular risk factors profiles in other Muslim countries are also worryingly. Among the Arab world, risk factors like central obesity are not only alarmingly high among the affluent countries of the Gulf States but also in less affluent Arab world of North Africa ${ }^{13}$. In Western countries, Muslims migrants have higher prevalence of cardiovascular risk factors not only compared to the native population ${ }^{14}$ but also compared to non Muslim migrant population $^{15}$. The same group of researchers have also demonstrated that Bangladeshi in $\mathrm{UK}$ have the worst $\mathrm{CV}$ risk profile compared to other migrants from South Asia ${ }^{14}$. There were also more baseline ECG abnormalities suggesting more prevalent silent coronary artery diseases among South Asian migrant population compared to European ${ }^{16}$. In Western Europe (outside the UK), although quality data is lacking, CV risk profile tended to be worse among Muslim migrants compared to the local population ${ }^{17}$.

The increase burden of CVD among the Muslims and that of the Indian Subcontinent in particular can be explained by the higher prevalence of traditional risk factors and not due to ethnicity per $s e^{18}$. In Pakistan, the risk of cardiovascular disease appears to similar between male and female, contrary to conventional thoughts ${ }^{19}$. This is partially attributed to the greater prevalence of hypertension among women and observation which is also seen in Malaysia where Malay women (almost all Muslims) have the highest prevalence of hypertension ${ }^{12}$. Cross sectional study from Egypt on the other hand 
demonstrated that the urban population demonstrated more adverse cardiovascular risk compared to rural folks ${ }^{20}$.

\section{Intervention programmes in the Muslim community}

This year in the month of September, the United Nation General Assembly will be highlighting the importance of a global strategy to combat non - communicable disease in general and cardiovascular disease in particular. Several stakeholders and interest groups have already started initiatives which will cut across borders in this noble effort at combating premature CVD worldwide. They include important scientific community like that of the Lancet NCD Action Group and the NCD Alliance ${ }^{21}$. Unfortunately despite CVD being a major problem in the Muslim world, no Muslim country is directly involved in many of these initiatives. One of a few Muslim countries which has taken the initiative is Malaysia which recently launched its own National Action Plan on Non Communicable Disease $^{22}$. The Gulf States realising that they are sitting on a CVD 'time bomb' have also taken some positive steps in curtailing the rising tide of CVD. This is well exemplified by efforts made by the United Arab Emirates ${ }^{23}$. The bidirectional 'top down' and 'bottom up' approach by Abu Dhabi is an interesting to look forward to and to emulate. It also aspires to develop CVD risk scoring systems which are more suited to the Muslim population. If proven successful, this model can be extended not only to other Muslim countries but also to other low and middle income countries. The' bottom up' approach is particularly important because it is ironic that despite the affluent lifestyle enjoyed by its populous, residents in the Gulf states demonstrates poor knowledge on important aspects of CVD ${ }^{24}$. What is most shocking was that knowledge was poorest among those with the highest risk. The same trend is seen among Muslim migrants to developed countries where Muslims (particularly of Bangladeshi origin) demonstrated poorer awareness of CVD than other South Asian migrant population ${ }^{25}$. Any meaningful intervention programme to be implemented should ideally be done early as is being undertaken in Turkey ${ }^{26}$.

Muslim nations and Muslim communities must realise that CVD is a major problem among them and if left unchecked will lead to many more premature morbid and mortal events. The evidence as discussed above is overwhelming and consistent. As such remedial measures must be instituted by all concerned. These will have to be multipronged, integrated and concerted. The scope of remedial measures to mitigate this epidemic is wide and must involve all relevant stakeholders from the public, to the health care providers, governmental and nongovernmental organisations. While it is tempting to repeat successful intervention models adopted in Western population like that of Scandinavia and the United Kingdom, issues peculiar to the Muslim ummah must also be addressed. The Organisation of Islamic Conference despite having a fairly well written blueprint of action ${ }^{6}$ did not seem to cover the issues of health in general and CVD in particular well. This will have to be rectified. In the mean time all relevant stakeholders including researchers must play their role with some urgency. Researchers should identify gaps in knowledge on aspects of CVD unique to our populations. These may include role of spirituality in CVD and adoption of an Islamic intervention programme involving religious leaders to spread the message of health and its importance to spirituality. There is almost no research on this from the Muslim world, at least in published English literature but others have published work which is intriguing and needs further verification ${ }^{27}$. While it may be unsuitable to subject elements of iman (faith) to experimental curiosity, nevertheless it's potential in the healing process must be adopted as part of the holistic approach in tackling CVD.

Important hindrances to implementing intervention programme must be identified. One such hindrance is the availability and affordability of proven intervention methods. A survey commissioned by WHO on essential medicine in selected low and middle income 
countries showed that treatment for cardiovascular disease is not widely available and not generally affordable especially in Bangladesh and Pakistan ${ }^{28 .}$ This is particularly so in the public sector. In terms of affordability, standard treatment for coronary artery disease in private sectors will cost a patients in Bangladesh equivalent to 1.6 days wage while in Pakistan 5.4 days wages. Malawi registered the worst result on affordability which was 18.4 days wages! It is however importantnt to note that in affluent Muslim countries like Qatar, despite availability of modern treatment to treat myocardial infarction, the utilisation rate is not optimum. What is even intriguing was that the acute response to therapy is not as good among local Qatari as that of the immigrant population $^{29}$. This is in contrast to observations in the West where the short term mortality rate is higher among migrants (mostly Muslims) compared to locals ${ }^{30}$. Long term mortality rate on the other hand is comparable to local population $^{31}$.

Observations from the Asia Pacific region remind us that it is important to monitor the effect of urbanization on cardiovascular risk profile ${ }^{32}$. Just like the Asia Pacific region, the other bloc of Muslim countries like the Eastern Mediterranean has also indentified regional approaches to tackle cardiovascular diseases ${ }^{33}$. Intervention programme instituted must also take into consideration cultural background of the targeted population. Evidence from Netherlands however rather surprisingly showed that intervention programme designed for Turkish immigrant conducted by female Turkish educators failed to improve diabetes control and CV risk profile ${ }^{34}$. Dutch diabetic patients unlike Turkish immigrants meanwhile benefitted from clinical practice guideline driven intervention ${ }^{35}$. This may suggest that in Muslim immigrant communities, intervention programme need also be gender specific not just ethnic specific. It is also disturbing to note that intervention among deprived immigrant population is Netherland as a whole failed to demonstrate and benefits on CV risk profile ${ }^{36}$. Reasons for these disappointing observations must be understood so that future intervention programmes may show more favourable outcomes.

\section{Cardiovascular Risk Reduction - Pearls from the Islamic Teaching}

Health is an integral part of the Islamic teaching. The Holy Quran clearly states that whoever saves the life of a person, it is as if he had saved the life of all mankind ${ }^{37}$. Prophet Muhammad's written traditions (Hadith) contained important advice on health ${ }^{38}$. The Islamic Divine Law (Syariah) was revealed to protect the best interest of human on earth ${ }^{39}$. It places five foundation goals of the Divine Laws (Maqasid As Syariah) of which protection of Life (Hifdh Nafs) is second only to the protection of Religion (Hifdh Deen). To achieve the goals of the Islamic Syariah, important principles or legal maxims are laid down $^{40}$ (Qawaid As Syariah). Many of these principles (qa'idat) have direct application to health. These include principles of intention (qa'idat al qasd), principle of certainty (qa'idat al yaqeen), principle of injury (qa'idat al dharar), principle of hardship (qa'idat al mashaqqat) and principle of custom (qa'idat al urf).

The heart has a special position in Islam. The Prophet said in a famous hadith "Beware, in the body there is a flesh; if it is sound, the whole body is sound, and if it is corrupt, the whole body is corrupt, and behold, it is the heart." 41 . Although this hadith specifically talks about the spiritual heart, the same principle can be applied to the physical heart. Early Muslim physicians like the illustrious Avicenna (Ibn Sina) had outlined important principles of cardiac diseases. Indeed Ibn Sina was the first physician to point out the relationship between cardiac disease and psychosocial make up of an individual ${ }^{42}$. Ibn Sina pioneered the field of cardiovascular therapeutics with detailed description of drugs for the heart, their indications and contraindications $^{43}$. Books on health incorporating prophetic traditions were also written after the golden era of Muslim contributions to medicine. The most famous being books written by Ibn Qayyim Al 
Jawziyyah and that of Jalaluddin As Suyuti both entitled the Prophetic Medicine (Tibb An Nabawi). Both authors however did not specifically elaborate on treatment of cardiovascular disease but in contained tips on healthy lifestyle from the prophetic traditions $^{44,45}$.

Many of what we now know about healthy lifestyle to prevent CVD have roots in the Islamic tradition. The Quran clearly states that Muslims should not only eat what is allowable (halal) but also what is halal and good for health (Halalan Tayyiban) ${ }^{46}$. The Quran also advocate moderation in whatever we do and not to be extravagant including when it comes to eating ${ }^{47}$. When eating, the Prophet (pbuh) advised Muslim to eat in moderation ${ }^{48}$. The Islamic teaching also encourages us to be healthy as the prophet said 'A strong Muslim is better than a weak Muslim but there is goodness in both. The prophet also encouraged us to walk in a dignified manner in a way described as Hauna ${ }^{49}$ which was interpreted by the famous commentator of the Quran, Ibn Kathir, as walking downhill with firm steps ${ }^{50}$ or brisk walking. The prophet himself is an epitome of health. At an age well pass his $50^{\text {th }}$ birthday, he can still engage himself in running competition with wife Aishah who was still a teenager and beat her at it. The practice of siesta, a Muslim tradition also known as
Kailullah, in the meantime has been linked to positive effects on $\mathrm{CV}$ profile ${ }^{51}$ and $\mathrm{CV}$ mortality ${ }^{52}$. Interestingly a recent study showed that the effect of intermittent energy restriction for 2 days a week produced similar $\mathrm{CV}$ benefits than that of continuous energy restriction for the whole week over a six month study period ${ }^{53}$. Muslims are encouraged by the prophets to fast two days a week on Mondays and Thursday and from this recent evidence this practice may help reduce CVD risk in the long run. Recent animal study also gave insight into the mechanistic benefits of intermittent fasting on CVD protection ${ }^{54}$.

\section{Conclusion}

As a recognised epidemic, CVD maybe new to the ummah but its presence is not. Metabolic syndrome was prevalent among the affluent even in pre modern era ${ }^{55}$ In contemporary times however it is not confined to the affluent among us. With the epicentre of the CVD epidemic poised to remain within the Muslim nations and Muslim communities for the foreseeable further, efforts must be initiated to systematically and strategically tackle this epidemic. Hopefully this short article will at least help to trigger some realisation on the importance of closing the CVD Pandora's Box which had been unleashed for some decade now.

\section{References}

1. He J, Gu D, Chen J et al Premature deaths attributable to blood pressure in China: a prospective cohort study. Lancet 2009 Nov 21; 374 (9703):1765-72. doi:10.1016/S0140-6736(09)61199-5.

2. Mather CD, Lopez AD, Murray CJL. Global Burden of Disease and Risk Factors 2006. Oxford University Press New York. ISBN -10: 0-8213-6202-3.

3. United Nations World Population Prospects: 2006 Revision. Table A.17 for 2005-2010 accessed at http://www.un.org/.esa/population/publicationon28/5/ 2011).

4. Central Intelligence Agency The World FactBook (http//:www.cia.gov/library/publication; accessed on 28/5/2011).

5. Kuhn R. Routes to low mortality in poor countries revisited. Popul Dev Rev. 2010; 36(4):655-92. doi:10.1111/j.1728-4457.2010.00353.x. PMid:21174865.

6. OIC Ten- Year Programme of Action (accessed from http://www.oic-oci.org/home.asp on the 29/5/11).

7. WHO Global Health Observatory Data Repository. Cause Specific Mortality 2008 from http://www.who.int/healthinfo/statisticsaccessed22/5/ 2011.

8. Ramaraj R, Chellappa P. Cardiovascular risk in South Asians. Postgrad Med J 2008; 84:518-523. doi:10.1136/pgmj.2007.066381. PMid:19017836. 
9. Tokgözoğlu L, Kaya EB, Erol C, Ergene O; EUROASPIRE III Turkey Study Group. [EUROASPIRE III: a comparison between Turkey and Europe]. Turk Kardiyol Dern Ars. 2010 Apr; 38(3):164-72. Turkish. PMid:20675993.

10. Boedhi-Darmojo R. The pattern of cardiovascular disease in Indonesia. World Health Stat Q. 1993; 46(2):119-24. PMid:8303906.

11. Benamer HT, Grosset D.Stroke in Arab countries: a systematic literature review. J Neurol Sci 2009; 284(1-2):18-23. doi:10.1016/j.jns.2009.04.029. PMid:19428027.

12. Institute of Public Health (IPH) 2008. The Third National Health and Morbidity Survey 2006 Vol. Ministry of Health Malaysia pg 199- 316 ISBN 978983-3887-30-9.

13. Harzallah F, Alberti H, Ben Khalifa F. The metabolic syndrome in an Arab population: a first look at the new International Diabetes Federation criteria. Diabet Med 2006; 23(4):441-4. doi:10.1111/j.14645491.2006.01866.x. PMid:16620275.

14. Bhopal R, Unwin N, White M, et al. Heterogeneity of coronary heart disease risk factors in Indian, Pakistani, Bangladeshi, and European origin populations: cross sectional study. BMJ 1999; 319:215-20. PMid:10417082. PMCid:28170.

15. Bennett PC, Lip GY, Silverman $S$ et al The contribution of cardiovascular risk factors to peripheral arterial disease in South Asians and Blacks: a sub-study to the Ethnic-Echocardiographic Heart of England Screening (E-ECHOES) study. QJM 2010: $103 \quad$ (9) :661-9. doi:10.1093/qimed/hcq102. PMid:20576717.

16. Fischbacher CM, Bhopal R,Unwin $\mathrm{N}$ et al The performance of the Rose angina questionnaire in South Asian and European origin populations: a comparative study in Newcastle, UK. Int $\mathrm{J}$ of Epidemiol 2001; 30(5):1009-16. doi:10.1093/ije/30.5.1009. PMid:11689512.

17. Uitewaal PJ, Bruijnzeels MA, Bernsen RM et al. Diabetes care in Dutch general practice: differences between Turkish immigrants and Dutch patients. Eur J Public Health. 2004 Mar; 14(1):15-8. doi:10.1093/eurpub/14.1.15.

18. Goyal A \& Yusuf S. The burden of cardiovascular disease in the Indian subcontinent. Indian J Med Res 124, September 2006, pp 235-244. PMid:17085827.

19. Jafar TH, Jafary FH, Jessani S, et al. Heart disease epidemic in Pakistan: women and men at equal risk. Am Heart J 2005; 150:221-6. doi:10.1016/j.ahj.2004.09.025. PMid:16086922.
20. Ibrahim MM, Appel LJ, Rizk HH, et al Cardiovascular risk factors in normotensive and hypertensive Egyptians. J Hypertens. 2001 Nov;19(11):1933-40. doi:10.1097/00004872200111000-00002. PMid:11677357.

21. Beaglehole R, Bonita R, Horton Ret al. Priority actions for the non-communicable disease crisis. Lancet 2011:377:1438-47. doi:10.1016/S01406736(11)60393-0.

22. Non Communicable Disaese Divison, Ministry of Health. National Strategic Plan for Non Communicable Disease. 2010 (First Edition). ISBN 978-983-3433-73-5.

23. Hajat C, Harisson O. The Abu Dhabi Cardiovascular Program: the continuation of Framingham. Prog Cardiovasc Dis 2010; 53(1): 28-38. doi:10.1016/j.pcad.2010.05.002. PMid:20620423.

24. Kamran S, Bener AB, Deleu D et al.The level of awareness of stroke risk factors and symptoms in the Gulf Cooperation Council countries: Gulf Cooperation Council stroke awareness study.

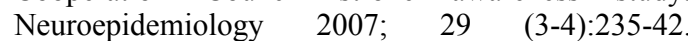
doi:10.1159/000112856. PMid:18176080.

25. Rankin J, Bhopal R. Understanding of heart disease and diabetes in a South Asian community: crosssectional study testing the 'snowball' sample method. Public Health 2001; 115(4):253-60. doi:10.1038/sj.ph.1900777. PMid:11464296.

26. Kirby MG. Cardiovascular disease prevention, screening and early detection in Turkey. Cardiology. 2010; 115(4):294-6. doi:10.1159/000312008. PMid:20395680.

27. Hollywell C, Walker J. Private prayer as a suitable intervention for hospitalised patients: a critical review of the literature. J Clin Nurs. 2009 Mar;18(5):637-51. PMid:19077024.

28. Mendis S, Fukino K, Cameron A, et al.The availability and affordability of selected essential medicines for chronic diseases in six low- and middle-income countries. Bulletin of the World Health Organization 2007; 85:279-288. doi:10.2471/BLT.06.033647. $\quad$ PMid:17546309 PMCid:2636320.

29. Hadi HA, Al Suwaidi J, Bener A et al Thrombolytic therapy use for acute myocardial infarction and outcome in Qatar. Int J Cardiol 2005; 102 (2):249-54. doi:10.1016/j.ijcard.2004.05.024. PMid:15982492.

30. Paul Wilkinson, Jeremy Sayer, Koorithottumkal et al Comparison of case fatality in south Asian and white patients after acute myocardial infarction: 
observational study. BMJ 1996; 312:1330-3. PMid:8646044. PMCid:2350987.

31. Mukhtar HT, Littler WA Survival after acute myocardial infarction in Asian and white patients in Birmingham. $\mathrm{Br}$ Heart J 1995;73:122-124. doi:10.1136/hrt.73.2.122.

32. Khor GL. Cardiovascular epidemiology in the AsiaPacific region. Asia Pac J Clin Nutr. 2001; 10(2):76$80 . \quad$ doi:10.1046/j.1440-6047.2001.00230.x. PMid:11710361.

33. Khatib O. Noncommunicable diseases: risk factors and regional strategies for prevention and care. East Mediterr Health J. 2004 Nov; 10 (6):778-88. PMid:16335764.

34. Uitewaal PJ, Voorham AJ, Bruijnzeels MA et al.No clear effect of diabetes education on glycaemic control for Turkish type 2 diabetes patients: a controlled experiment in general practice. Neth $\mathrm{J}$ Med. 2005 Dec; 63(11):428-34. PMid:16397311.

35. Uitewaal PJ, Manna DR, Bruijnzeels MA, Hoes AW, Thomas S Prevalence of type 2 diabetes mellitus, other cardiovascular risk factors, and cardiovascular disease in Turkish and Moroccan immigrants in North West Europe: a systematic review. Prev Med. 2004 Dec; 39(6):1068-76. doi:10.1016/j.ypmed.2004.04.009. PMid:15539038.

36. El Fakiri F, Bruijnzeels MA, Uitewaal PJ et al.Intensified preventive care to reduce cardiovascular risk in healthcare centres located in deprived neighbourhoods: a randomized controlled trial. Eur J Cardiovasc Prev Rehabil. 2008 Aug;15(4):488-93. doi:10.1097/HJR.0b013e3282fceac2.

37. Al Quran Chapter 5 (Al Maidah): verse 32.

38. Fazlul Karim. Al Hadis 1939 Section 1. Diseases and Treatment pg 68-89. The Book House. Lahore.

39. http://www.muslimphilosophy.com/ma/works/maqasi d.pdf accessed on $28 / 5 / 2011$

40. Kamali MH. Qawa'id al- Fiqh: The Legal Maxim of Islamic Law accessed from http://www.sunnah.org/figh/usul/KamaliQawaidalfigh.pdf.

41. An- Nawawi 40 Hadith's.com (accessed from www.40hadith.com on 28th May 2011).

42. Said M. Ibn-Sina's concept of cardiovascular diseases. Bull Indian Inst Hist Med Hyderabad 1995; 25 (1-2):129-34. PMid:11618832.
43. Ali M. Avicenna's approach to cardiac diseases. Bull Indian Inst Hist Med Hyderabad 1993; 23(2) :137-41. PMid:11639484.

44. Isa RM. Prophetic Medicine. 1996. Thinkers Library Orient Press Sdn Bhd. Malaysia ISBN 967-69-01539.

45. Aziz NA. Prophetic Medicine. Synergy Publication, Kuala Lumpur, ISBN 983-136-950-5.

46. Al Quran Chapter 5 (Al Maidah): verse 88.

47. Al Quran Chapter 7 (Al A'raf): verse 31.

48. Karim F. Al Hadis. The Book House Lahore Vol 11 pg 132.

49. Al Quran Chapter 25 (Al Furqan): verse 63.

50. Ad Dimasyqi. Tafsir Ibn Kathir (Malay Translation) 2004; vol 19 pp70. Sinar Baru, Bandung ISBN 979670-059-X.

51. Stang A, Dragano N, Poole C et al Daily siesta, cardiovascular risk factors, and measures of subclinical atherosclerosis: results of the Heinz Nixdorf Recall Study. Sleep. 2007 Sep; 30(9):1111-9. PMid:17910383. PMCid:1978397.

52. Naska A, Oikonomou E, Trichopoulou A et al Siesta in healthy adults and coronary mortality in the general population Arch Intern Med. 2007;167(3):296-301.

doi:10.1001/archinte.167.3.296. PMid:17296887.

53. Harvie MN, Pegington M, Mattson MP et al. The effects of intermittent or continuous energy restriction on weight loss and metabolic disease risk markers: a randomized trial in young overweight women. Int $\mathrm{J}$ Obes (Lond). 2011 May;35(5):714-27. doi:10.1038/ijo.2010.171. PMid:20921964. PMCid:3017674

54. Wan R, Ahmet I, Brown M, et al. Cardioprotective effect of intermittent fasting is associated with an elevation of adiponectin levels in rats. $\mathrm{J}$ Nutr Biochem. $2010 \quad$ May; 21(5):413-7. doi:10.1016/i.jnutbio.2009.01.020. PMid:19423320. PMCid:2854256.

55. Dağdelen S, Erbaş T.Disease of the Sultans: metabolic syndrome in Ottoman dynasty. Anadolu Kardiyol Derg. 2010 Jun;10(3):270-3. doi:10.5152/akd.2010.069. 